\title{
Peran Taman Nasional bagi Pembangunan Nasional Era New Normal
}

\author{
Pungky Widiaryanto ${ }^{1}$
}

\begin{abstract}
Afiliasi
${ }^{1}$ Staf Perencana di Kementerian Perencanaan Pembangunan Nasional/Bappenas

Republik Indonesia.
\end{abstract}

\section{Korespondensi: pungky.widiaryanto@bappenas.go.id}

\begin{abstract}
Abstrak
Turisme alam di masa new normal, akibat pandemi Covid-19, akan menjadi sebuah tren. Sebagian besar lokasi wisata alam ini berada di taman nasional. Permasalahannya, penetapan taman nasional bukan seolah-olah hanya untuk destinasi wisata. Selain pariwisata, taman nasional juga berfungsi perlindungan keanekaragaman hayati, tempat tinggal masyarakat lokal, bahkan mempunyai nilai politis. Berkaca dari hal tersebut, tulisan ini mencoba membedah arti dan makna taman nasional bagi bangsa Indonesia dilihat dari beberapa sudut pandang. Penulisan artikel ini menggunakan pendekatan ekologi politik dengan mengulas beberapa pustaka tentang sejarah penetapan dan perkembangan taman nasional. Pandangan ekologi politik memungkinkan untuk mengkaji taman nasional dilihat dari aspek ekologi, sosial, ekonomi, dan politik. Berdasarkan hasil analisis, beberapa makna taman nasional: sebagai destinasi wisata, identitas nasional, kawasan konservasi, dan tempat tinggal suku adat. Perbedaan pandangan taman nasional tersebut justru dapat menjadi peluang taman nasional sebagai wujud nyata penerapan pembangunan berkelanjutan, khususnya melalui instrumen pariwisata berkelanjutan. Integrasi nilai-nilai tersebut juga memungkinkan taman nasional sebagai agen pembangunan berkelanjutan di lapangan. Di akhir, tulisan ini memaparkan rekomendasi beberapa program untuk mewujudkan konsep pariwisata berkelanjutan pada taman nasional dengan memperhatikan protokol tatanan baru atau new normal akibat pandemi Covid-19.
\end{abstract}

Kata Kunci: taman nasional, wisata alam, sejarah, new normal

Doi: https://doi.org/10.47266/bwp.v3i2.77 | halaman: 184-198

Dikirim pada: 23 Juli 2020. Diterima pada: 1 September 2020. Dipublikasikan pada: 07 September 2020 


\section{Latar Belakang}

Pandemi Covid-19 telah mengubah tatanan kehidupan di dunia. Dampaknya mulai dari ekonomi, cara bekerja, hingga perilaku manusia. Pandemi ini juga berpengaruh terhadap pola pariwisata. Wisata berbasis alam diyakini menjadi favorit bagi masyarakat umum setelah menjalani Pembatasan Sosial Berskala Besar (PSBB).

Setelah masyarakat menjalani isolasi di dalam dan sekitar rumah selama PSBB, ada rasa untuk berwisata. Banyak survei dan pengamat memprediksi bahwa wisata akan menjadi pilihan utama masyarakat untuk berlibur (Chen, K. dkk, 2020). Penyebabnya antara lain menikmati pemandangan dan udara segar di alam setelah jenuh di rumah, mempunyai resiko rendah terhadap tertularnya Covid-19, dan memungkinkan untuk menjaga jarak dengan orang lain.

Aktivitas wisata alam pun bisa bermacammacam. Contohnya adalah treking, hiking, mendaki gunung, menikmati agrowisata, rafting, camping, hingga kegiatan di lautan seperti snorkling dan diving. Tempatnya pun beragam, mulai dari gunung, pantai, laut, hutan, hingga sekedar taman kota. Di Indonesia, warga negara patut bersyukur karena terdapat banyak destinasi wisata alam. Salah satunya adalah Taman Nasional.

Indonesia saat ini mempunyai 54 taman nasional yang tersebar dari Sabang sampai Merauke. Ada yang berupa hutan tropis, gunung, savana, hingga lautan. Keindahan alam dan keanekaragaman hayati tersebut menjadikan taman nasional sebagai destinasi wisata. Bahkan beberapa taman nasional, seperti Taman Nasional Komodo, Taman Nasional Bromo Tengger Semeru, dan Taman Nasional Wakatobi telah ditetapkan pemerintah sebagai destinasi wisata prioritas. Artinya, taman-taman tersebut akan dikembangkan sehingga diharapkan dapat menarik pengunjung baik dari nusantara maupun mancanegara. Harapannya adalah pengembangan pariwisata prioritas tersebut dapat menggerakkan dan meningkatkan pertumbuhahan ekonomi baik regional maupun nasional.

Di sisi lain, tujuan ditetapkan taman nasional bukan seolah-olah hanya untuk destinasi wisata. Banyak masyarakat umum kurang paham dan mengerti tentang taman nasional. Ada yang berpendapat taman nasional merupakan sumber daya alam potensial sebagai pariwisata seperti yang dikemukan sebelumnya. Namun, sebagian masyarakat juga berpendapat bahwa taman nasional merupakan suatu kawasan untuk konservasi atau dilindungi. Ada juga yang berpendapat bahwa taman nasional mempunyai fungsi sosial karena di dalam taman nasional terdapat masyarakat lokal dan atau suku adat yang telah lama tinggal.

Ketiga pandangan tersebut terkadang menjadi hambatan dalam mengoptimalkan potensi taman nasional. Sebagai contoh, ahli ekonomi memandang taman nasional sebagai potensi ekonomi dari sektor pariwisata, sehingga perlu adanya pembangunan infrastruktur dalam taman. Di pihak lain, para pecinta lingkungan merasa bahwa pengembangan sarana dan prasarana yang masif akan merusak ekosistem. Sementara para aktivis sosial memandang bahwa pengembangan wisata di taman nasional akan meningkatkan jurang kesenjangan, terutama bagi masyarakat lokal.

Dengan mempertimbangkan pengelolaan taman nasional masih dalam perdebatan dan berpengaruh terhadap rencana ke depan, maka relevan untuk mengkaji alasan sejarah peruntukan taman nasional di Indonesia. Berdasarkan sejarah, beberapa ahli telah mengkaji awal pembentukan taman nasional mulai abad ke-19 di Indonesia (saat itu masih Hindia Belanda). Pembentukan taman nasional tidak hanya dilihat dari nilai ekologi saja, namun ada nilai sosial, politik, dan ekonomi (Jepson dan 
1. Lat ar belakang dan permasalahan

Wisata alam taman nasional menjadi tren di masa pandemi dan nevo normal. Namun. peran taman nasional tidak hanya sebagai destinasi wisata (elkonomi) tapi juga ada fun gsi elologi dan sosial. Banyalk masyarakat umum pun tidak mengetahui arti dan makna taman nasional

\section{a. Research question}

Apa sebenamya arti taman nasional?

Bagaimana peran atau malkna taman nasional dal am mewujudkan pembangunan berkelanjutan melalui pariwisata berkel anjutan khususnya era nesv normal?

s. Pengumpulan bahan

Men gumpulkan pustalka terkait ten tang sejarah, definisi, kategori, dan peran taman nasional.

Melakukan pengamatan berdasarkan pengalaman sebagai perencana konservasi alam

4. Analisis

Melakukan penelahaan men ggunakan pendekatan ekologi poltik berdasarkan bahan, observasi sebagai perencana, dan pengalaman kunjungan ke beberapa taman nasional di Indonesia.

5. Kesimpulan dan rekomendasi

Menyusun sintesa

Menyusun rekomendasi kebijalkan

Gambar 1. Kerangka Berpikir Penelitian

Whittaker, 2002). Dengan melihat pertimbangan sejarah pembentukan taman nasional diharapkan dapat memahami makna taman nasional dan juga arah pembangunan taman nasional di masa datang.

Untuk itu, tulisan ini mencoba membedah arti dan makna taman nasional bagi bangsa Indonesia dilihat dari beberapa sudut pandang. Sementara itu, masa new normal seperti sekarang ini juga menjadi tantangan sekaigus peluang bagi taman nasional. Seperti diulas sebelumnya, pariwisata alam, khususnya di taman nasional, diharapkan menjadi salah satu pendongkrak pemulihan ekonomi akibat pandemi Covid-19. Berdasarkan latar belakang permasalahan adanya perbedaan pandangan dan juga peluang menjadikan taman nasional sebagai salah satu faktor penggerak ekonomi masa pandemi, maka penulis mencoba merumuskan pertanyaan kunci: Apa arti kehadiran taman nasional bagi bangsa Indonesia? Bagaimana peran taman nasional dalam pembangunan? Di akhir tulisan ini, penulis mencoba menawarkan rekomendasi persiapan taman nasional untuk mendukung pariwisata utamanya di era new normal.

\section{Metode}

Guna menjawab pertanyaan kunci di atas khususnya menggali arti dan makna tentang taman nasional, secara konseptual, kerangka penulisan karya ini dimulai dari pemaparan sejarah taman nasional di dunia. Melalui pendekatan sejarah maka dapat digambarkan mengenai dasar dan makna pengelolaan sumber daya alam (McManus, 1999). Diharapkan dari pandangan sejarah ini dapat memberikan gambaran asal-usul alasan adanya taman nasional, khususnya dari pengalaman Amerika Serikat sebagai pencetus ide taman nasional pertama di dunia.

Kemudian, bab selanjutnya akan membahas lahirnya taman nasional di Indonesia guna memahami tujuan awal penetapan taman nasional di Indonesia. Berdasarkan kedua 
sejarah tersebut (global dan nasional), penulis akan mengulas beberapa makna taman nasional. Dari analisis beragam makna taman nasional tersebut, pada bagian terakhir, karya tulis ini memaparkan rekomendasi kebijakan pengembangan taman nasional sebagai destinasi wisata, khususnya di era new normal. Untuk memudahkan dalam memahami kerangka berpikir artikel ini, penulis mencoba menggambarkan melalui diagram pada gambar 1.

Penulisan artikel ini menggunakan pendekatan ekologi politik. Pendekatan ini penting untuk memahami perbedaan pandangan atau pendapat terhadap taman nasional dengan menggabungkan antara aspek ekologi, sosial, ekonomi, dan politik (Robbins, 2019). Beberapa pustaka pilihan dan tersistematis akan dijadikan dasar dalam menganalisis. Selain itu, penulisan artikel ini juga didasarkan pengalaman penulis sebagai perencana bidang konservasi alam, salah satunya program pembangunan taman nasional. Pengalaman tersebut tidak hanya saat menyusun perencanaan dan anggaran saja, namun juga pengalaman berinteraksi dan berdiskusi dengan para pengelola taman nasional di Indonesia. Pengalaman ini akan memperkaya artikel ini terutama dalam mendalami arti dan juga makna taman nasional. Untuk memudahkan dalam melihat metode penulisan artikel ini, penulis mencoba membuat bagan seperti tertera gambar 2 .

\section{Sejarah dan Definisi Taman Nasional}

Taman nasional, diakui atau tidak, adalah hasil doktrinisasi Amerika Serikat. Konsep ini diciptakan di Amerika Serikat pada abad ke-19. Kemudian sukses diadopsi hampir di seluruh dunia. Orang-orang Amerika Serikat bahkan

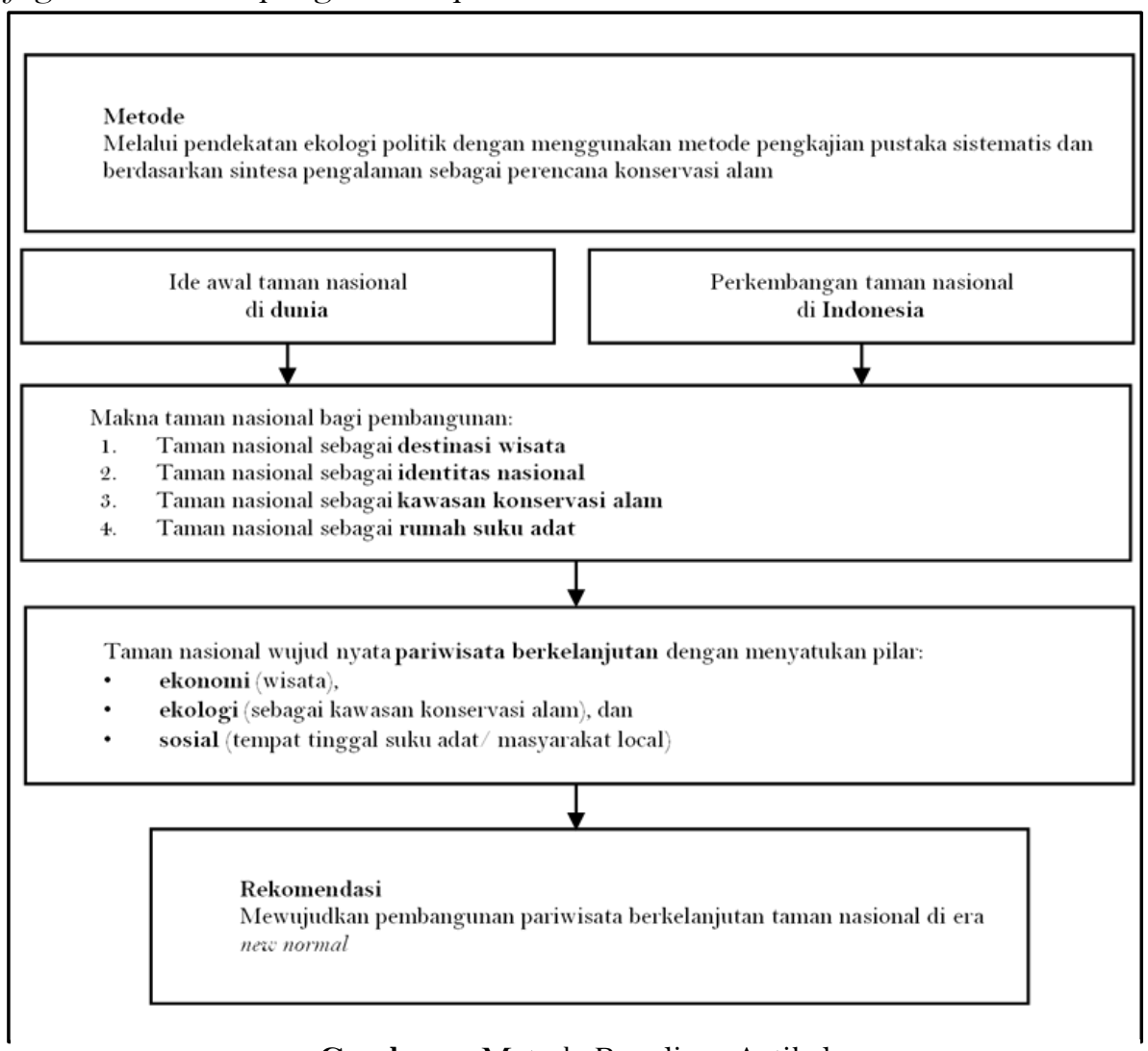

Gambar 2. Metode Penulisan Artikel 
mendeklarasikan taman nasional adalah ide terbaik mereka. Tapi pada akhir abad ke-20, banyak ahli mulai meninjau kembali ide taman nasional sebagai konsep sempurna untuk melestarikan alam secara kritis. Di sisi lain, taman nasional memberikan kontribusi terhadap pemikiran baru guna memahami hubungan antara manusia dan alam (Haines, 1996).

Mari kita telusuri sejarah ide taman nasional yang berasal dari Amerika Serikat itu. Pada pertengahan abad 19, sebuah tim kecil visioner dan idealis mencoba mengajukan demokrasi dalam lanskap (Runte, 2010). Mereka menganggap keindahan Amerika Serikat seharusnya tidak selalu untuk dieksplotasi. Sebaliknya, negara harus mengalokasikan dan melestarikan keindahan panorama.

Pelan tapi pasti, persepsi mengenai lingkungan berubah. Mengawetkan hidupan liar dan perlindungan alam menjadi sama pentingnya dari sekedar mempertahankan keindahan panorama. Kendati demikian, Amerika Serikat sendiri masih memperdebatkan makna taman nasional.

Perdebatannya seputar kawasan mana yang harus dilindungi dan bagaimana. Meskipun banyak pihak lebih tertarik terhadap fungsi ekologi dan lingkungan, tapi banyak orang Amerika Serikat ingin menikmati keindahan pemandangan taman nasional. Meskipun banyak penggiat konservasi mengkampanyekan untuk mengubah persepsi ini, namun pemahaman tentang taman nasional ada di tangan masyarakat. Soal apakah dan bagaimana taman nasional memberikan dampak bagi keanekaragaman hayati adalah pemikiran terakhir.

Dari makna harfiah, taman atau park berasal dari kata parc, yang berasal dari bahasa Perancis dan Inggris lama (Runte, 2010). Arti kata parc adalah kawasan tempat berburu para Raja . Barang siapa yang memasuki kawasan ini akan dihukum. Istilah ini dipakai para raja-raja dari Kerajaan Roma, Yunani, Persia, dan kerajaan yang ada di Asia.

Di era modern, terutama di perkotaan, taman identik dengan ruang terbuka hijau. Peruntukannya pun bermacam-macam. Mulai dari taman kota, hutan kota, hingga makam. Namun makna taman di sini adalah tempat untuk dinikmati masyarakat umum. Aktivitasnya bisa dari olahraga, sekedar kumpul atau tempat bertemu. Taman kota di Amerika Serikat yang sering kita dengar adalah Central Park di New York (Runte, 2010).

Tapi sesungguhnya, warga negara Amerika Serikat ternyata menginginkan lebih atas taman nasional. Jika taman kota masih dekat dengan hiruk-pikuk kota, publik menginginkan sebuah tempat yang tenang dan indah. Banyak warga negara Amerika Serikat yang tertarik dengan konsep taman yang berada di luar perkotaan, masih alami, dan mempunyai pemandangan menakjubkan. Sederhananya taman nasional adalah tempat yang alami dan jauh dari kota.

\section{a. Yellowstone Bukan yang Pertama}

Publik mengetahui bahwa taman nasional pertama di dunia adalah Taman Nasional Yellowstone. Tanggal peresmiannya pada 1 Maret 1872. Meski di dalam sempat terjadi perdebatan saat membentuk Yellowstone, tapi model taman nasional ini sukses direplikasi di seluruh negara bagian di negeri tersebut. Bahkan berbagai negara di dunia mengadopsi taman nasional tersebut. Termasuk Indonesia. Lalu bagaimana bisa Pemerintah Amerika Serikat dapat meresmikan taman tersebut untuk pertama kalinya.

Dalam buku "National parks: the American experience," Alfred Runte (2010) mengatakan Yellowstone sebenarnya bukan taman nasional pertama di Amerika Serikat. Ada tempat lain yang lebih cocok menjadi taman nasional dilihat dari keindahan alamnya. Taman Yosemite 
sebenarnya lebih cocok karena memiliki geyser, air terjun, ngarai, dan budaya. Menariknya kedua kawasan alam tersebut sama-sama berada di Amerika Serikat bagian barat.

Siapa yang pertama, Yellowstone atau Yosemite, sampai saat ini masih diperdebatkan. Faktanya, Yosemite adalah kawasan konservasi pertama yang ditunjuk oleh pemerintah pusat Amerika Serikat, yang diatur oleh keputusan presiden saat itu, Abraham Lincoln di tahun 1864 (Runte, 2010). Namun, wilayah Yosemite masih berada di bawah wewenang negara bagian California saja, dan tidak menjadi bagian dari sistem taman nasional pusat sampai 1890.

Adapun pemilihan Yellowstone sebenarnya lebih didasarkan politik. Taman ini terhampar di tiga negara bagian, dan kemudian dimiliki serta dikelola oleh pemerintah pusat Amerika Serikat. Dewan Perwakilan Rakyat (Conggress) Amerika Serikat menetapkan Yellowstone pada 1872 sebagai taman yang dikelola pusat. Oleh karena itu, Yellowstone secara umum diakui sebagai taman nasional pertama di dunia (Runte, 2010).

Banyak orang beranggapan pendirian Taman Nasional Yellowstone adalah untuk tujuan konservasi alam. Tidak sepenuhnya salah. Namun, ternyata gagasan taman nasional pertama ini berasal dari sebuah perusahaan kereta api North Pacific yang berencana untuk memperpanjang jalurnya hingga ke Yellowstone (Runte, 2010). Tujuannya ingin memperluas pangsa turis yang berkunjung ke Amerika Serikat bagian barat.

Sekitar tahun 1860, banyak masyarakat Amerika Serikat yang sudah mengetahui keindahan Yellowstone. Beberapa pecinta alam sudah melakukan ekspedisi ke daerah tersebut. Pada tahun 1870, perusahaan kereta api North Pacific kemudian membiayai sebuah kelompok Washburn-Doane untuk melakukan ekspedisi (Haines, 1996). Yang dicari adalah rancangan jalur kereta api dan destinasi wisata.
Ekspedisi menemukan obyek wisata tersebut ternyata sukses. Berbagai publikasi disebarkan. Peserta ekspedisi diundang di manamana untuk menceritakan keindahan Yellowstone. Perusahaan kereta api tersebut merasa puas dengan hasil ekspedisi (Runte, 2010). Untuk terus mempromosikannya, sastrawan juga didanai ke sana untuk melukis keindahan Yellowstone.

Setelah ekspedisi tersebut, konsep taman nasional dibahas anggota dewan Amerika Serikat. Mereka menjaring persepsi dan keinginan dari masyarakat. Sebagian besar warga Amerika Serikat masih memandang bahwa tujuan taman nasional untuk kepentingan ekonomi (wisata) daripada ekologi. Karena banyak yang setuju, dewan akhirnya membuat peraturan untuk menetapkan Yellowstone sebagai taman nasional (Runte, 2010).

Penetapan ini pun juga tidak terlepas dari lobi perusahaan kereta api. Sebagai imbal balik, dewan mengizinkan perusahaan tersebut memperpanjang rel-nya sampai dengan Yellowstone. Dengan adanya taman nasional ini, perusahaan kereta tersebut mendapatkan untung dari transportasi. Jadi demi meraup keuntungan, sebuah perusahaan kereta api mengeluarkan uang baik untuk ekspedisi, promosi, hingga lobi politik.

\section{b. Yellowstone sebagai Model Dunia}

Konsep taman nasional Yellowstone kemudian diadopsi oleh dunia. Pertanyaannya: konsep seperti apa yang diadopsi?

Bagi Amerika Serikat, permasalahan kepemilikan lahan nyaris tidak ada. Taman nasional dianggap tanah yang bersih dari aktivitas lainnya. Untuk menegakkan hal tersebut, peraturan dibuat secara kaku. Antara lain menyebutkan bahwa taman nasional merupakan tempat dilindungi, dan segala pemukiman, hunian dan tanah menjadi milik negara Amerika Serikat (Haines, 1996). 
Kawasan tersebut dijadikan taman publik dan tempat yang dapat dinikmati bersama. Bagi masyarakat yang nekat memasuki dan menetap di dalam taman, maka akan dianggap sebagai pelanggar, dan dihukum. Peraturan ini juga memuat ketentuan taman nasional dikelola oleh instansi pemerintah pusat.

Intinya, elemen utama dari undangundang ini, yang kemudian menjadi definisi taman nasional di seluruh dunia, adalah kepemilikan dan pengelolaan taman berada di bawah pemerintah pusat. Selain itu ditetapkan larangan pemukiman dan perumahan di dalam taman. Taman dijadikan tempat rekreasi publik dan perlindungan alam. Ketentuan iniwalaupun menuai debat dan kontroversiakhirnya menjadi kerangka hukum definisi taman nasional (Runte, 2010).

Ide taman nasional kemudian menyebar di seluruh dunia pada awal 1900-an, terutama pada daerah jajahan bangsa Eropa. Dorongan pembentukan taman nasional di kancah global sangat kompleks. Naik dan turunnya kekuasaan Eropa sangat berpengaruh terhadap inisiasi ini.

Pada awal abad ke-20, bangsa-bangsa di Eropa mencapai puncak kekuasaan, para pemburu, ilmuwan, dan dermawan berlombalomba membuat suatu perkumpulan atau organisasi perlindungan alam di daerah jajahan. Kejadian Perang Dunia II bagaimanapun juga telah mempengaruhi pembentukan taman nasional di berbagai belahan dunia.

Setelah perang dunia berakhir, kondisi politik internasional dan munculnya kerja sama global telah mengubah pertumbuhan taman nasional. Ini dimulai dengan pendirian the United Nations Educational, Scientific, and Cultural Organizations (UNESCO) pada 1947. Di bawah forum ini, ada banyak negara dan organisasi yang tertarik pada taman nasional. Kemudian dibentuklah the International Union for the Conservation of Nature and Natural Resources (IUCN), yang kemudian berubah menjadi World
Conservation Union. Institusi antar bangsa ini di dirikan pada 1948 dibawah naungan UNESCO. Tugasnya adalah mengoordinasikan dan mengatur definisi konservasi alam di tingkat global. Tujuan utamanya untuk menilai, memetakan, dan menyusun kawasan konservasi di dunia. Selain itu, lembaga ini juga bertugas untuk mengadakan kongres dunia taman nasional, dan juga menciptakan sistem klasifikasi kawasan konservasi (Haines, 1996).

Di bawah sistem klasifikasi IUCN, taman nasional diartikan sebagai suatu kawasan alam darat dan/atau laut, yang ditujukan untuk 1) melindungi satu kesatuan ekologi dari minimal satu ekosistem, 2) mengeluarkan eksploitasi atau pemukiman, 3) sarana kegiatan spiritual, penelitian, pendidikan, rekreasi, dan kesempatan berwisata (Wiratno, 2004). Ciri lainnya adalah penguasaan dan pengelolaannya di bawah kendali pemerintah pusat.

Di sini terlihat, definisi IUCN sangat mencerminkan konsep Yellowstone. IUCN ingin membakukan definisi kawasan konservasi. Padahal tidak semua negara setuju dengan model ini. Contohnya di Eropa, peraturan taman nasional mengizinkan adanya eksploitasi dan peruntukan lainnya. Tidak aneh di dalam taman nasional bisa terdapat kota, desa, lahan pertanian, tambang, dan aktivitas penebangan kayu.

Variasi definisi di internasional tentang taman nasional tersebut mengisyaratkan akan pentingnya konteks politik, budaya, dan sejarah masing-masing negara. Perdebatan antar negara pun tak dapat dihindari. Meski demikian, setiap negara sebenarnya berhak menentukan sendiri definisi tersebut.

\section{Lahirnya Taman Nasional di Indonesia}

Lahirnya taman nasional di Amerika Serikat kemudian mendorong pemerintah Hinda Belanda untuk mengikutinya, kendati tak menggunakan istilah yang serupa. Belanda 
ketika itu menggunakan istilah untuk sebuah kawasan konservasi dengan sebutan monumen alam atau Natuurmonumenten, dan suaka margasatwa atau Wildreservaten. Dua kawasan inilah cikal bakal keberadaan taman nasional di Indonesia. Di periode awal, menurut Jepson dan Whittaker (2002) ada dua kawasan yang ditetapkan sebagai taman nasional, yakni Lorentz di Papua dan Ujung Kulon di Jawa Barat. Lorentz ditetapkan tahun 1919, sedangkan Ujung Kulon pada 1921.

Penetapan taman nasional baru terjadi lagi setelah Indonesia merdeka. Tepatnya di era 1980-an. Secara bertahap, awalnya pemerintah menetapkan lima taman nasional, hingga menjadi 54 seperti sekarang ini. Sayangnya, peningkatan jumlah itu tak diikuti perubahan mendasar tentang konsep taman nasional. Prinsip pengelolaan taman nasional masih mengadopsi sistem kolonial hingga saat ini: mulai dari peta kawasan hingga konsep taman nasional harus bersih dari unsur manusia. Walhasil seperti yang kita lihat saat ini, karena masih mengadopsi sistem kolonial, prinsip pengelolaan taman nasional identik seperti cara Belanda mengurus daerah jajahannya.

Pasca-kemerdekaan, isu konservasi seolah hilang di Indonesia. Banyak faktor yang mempengaruhi. Salah satunya Indonesia sebagai negara baru ketika itu sedang mencari jati diri. Sistem pemerintahan dan politik terus berganti. Tak ada hal yang baru dan berubah dari keberadaan kawasan konservasi yang sebelumnya sudah ada di zaman kolonial. Peraturan perundangan ketika itu juga tidak ada yang menyebutkan istilah taman nasional. Bahkan, menurut Boomgard (1996) peraturan mengenai kawasan konservasi masih meniru peraturan Belanda tahun 1932 dan 1940.

Di kalangan internasional, era 1947-1991 merupakan masa perang dingin antara Amerika dan Rusia. Di awal tahun perang itu, para konservasionis internasional belum membahas tentang taman nasional ataupun konservasi. Baru sekitar tahun 1970-an, banyak lembaga internasional mulai mempromosikan dan mempengaruhi negara-negara baru untuk membentuk taman nasional.

Pada konteks Indonesia, intervensi lembaga internasional ini sangat berpengaruh. Pada 1974, organisasi internasional di bidang pertanian dan pembangunan, Food and Agriculture Organization-United Nations Development Programme (FAO-UNDP), memberikan bantuan untuk pembentukan taman nasional dan kawasan konservasi lainnya di Indonesia. Proyek itu dikenal dengan nama Nature Conservation and Wildlife Management antara 1974-1978 (Kusumasumantri, 2016). Tujuan proyek ini untuk memetakan data konsevasi alam dan pengelolaan satwa liar di Indonesia.

Para peneliti asing didatangkan ke Indonesia. Salah satu yang terkenal adalah John MacKinnon. Bekerjasama dengan ahli dari dalam negeri, MacKinnon mencoba menentukan kawasan konservasi di Indonesia dengan metode skoring. Pada masa itu, Mackinnon dan tim pergi ke berbagai kawasan konservasi di Indonesia. Mengingat waktu dan akses yang susah, tim hanya mengunjungi beberapa titik yang terjangkau. Pemetaan masyarakat, terutama yang telah lama tinggal di dalam kawasan, masih luput dari proyek ini.

Meski demikian, proyek ini dinilai berhasil. Proyek berlanjut ke tahap kedua pada 1979-1982, dengan nama National Park Development Project. Fokus proyek membentuk taman nasional. Berbagai upaya dilakukan mulai dari menganalisa calon kawasan, menyiapkan rencana pengelolaan, sampai dengan lobi dengan pemangku kebijakan.

Menurut Kusumasumantri

(2016) sedikitnya ada tiga capaian dari proyek ini. Pertama, dengan bantuan proyek tersebut, Pemerintah Indonesia mendeklarasikan lima 
taman nasional pada 1980. Lima taman nasional ini adalah Leuser, Ujung Kulon, Gede Pangrango, Baluran, dan Komodo. Kedua, proyek ini membuat percaya diri para pemangku kepentingan untuk menjadi tuan rumah Kongres Taman Nasional Sedunia III pada 1982 di Bali. Pada saat itu, 11 taman nasional juga dideklarasikan: Kerinci Seblat, Bukit Barisan Selatan, Seribu, Bromo Tengger Semeru, Bali Barat, Tanjung Puting, Kutai, Lore Lindu, Dumoga Bone, dan Manusela. Ketiga, proyek ini juga menghasilkan dokumen National Conservation Plan (NCP). Dokumen ini memuat profil kawasan konservasi seluruh Indonesia, dan rekomendasi peruntukannya. Sebenarnya komponen proyek ini merupakan "titipan” dari IUCN, WWF, dan UNEP. Pada 1980, ketiga konsorsium lembaga internasional itu ingin menyusun World Conservation Strategy. Saat itu, pendanaan konservasi dapat dibilang sangat terbatas. Walhasil ketika ada bantuan luar negeri, pemangku kepentingan kawasan konservasi langsung menerimanya.

Menurut Wiratno (2004), dalam bukunya Berkaca di Cermin Retak, dokumen NCP tersebut kemudian menjadi dasar dalam penyusunan Undang-Undang No. 5 tahun 1990 tentang Konservasi Sumber Daya Alam Hayati dan Ekosistemnya. Di peraturan inilah, istilah taman nasional baru muncul secara legal di Indonesia. Berdasarkan Undang-Undang tersebut, "taman nasional adalah kawasan pelestarian alam yang mempunyai ekosistem asli, dikelola dengan sistem zonasi yang dimanfaatkan untuk tujuan penelitian, ilmu pengetahuan, pendidikan, menunjang budidaya, pariwisata, dan rekreasi”.

\section{Makna Taman Nasional}

\section{a. Taman Nasional Sebagai Destinasi Wisata}

Dari cerita pembentukan Yellowstone, kita tahu bahwa tujuan utama taman nasional adalah keinginan para pengusaha, terutama industri kereta api. Pengusaha ini berharap mendapatkan keuntungan dari kenaikan penumpang. Misalnya setelah Yellowstone menjadi taman nasional, jumlah wisatawan ke taman tersebut meningkat sangat tajam. Salah satu faktornya adalah pembangunan jalur kereta lintas negara bagian pada 1869.

Tidak hanya bagi perusahaan kereta api, pemerintah pun mendapatkan manfaat dari kegiatan wisata. Tempat yang tadinya sepi menjadi roda penggerak ekonomi. Hotel-hotel dibangun. Rumah makan dan tempat suvenir menjamur. Pengunjung dari dalam dan luar negeri terus berdatangan. Bahkan sering terjadi kemacetan di Yellowstone saat liburan.

Di berbagai belahan dunia, termasuk Indonesia, beberapa taman nasional dibentuk karena alasan wisata juga. Tak heran, saat ini beberapa destinasi wisata prioritas berada pada taman nasional. Misalnya Bromo Tengger Semeru, Kepulauan Seribu, Wakatobi, dan Komodo. Dan masih banyak taman nasional lainnya yang mendukung destinasi wisata baru. Bagi pemerintah daerah, utamanya yang mengajukan lahannya untuk dijadikan taman nasional, juga berpikiran yang sama. Harapan mereka: taman nasional dapat menjadi sumber pendapatan baru.

Di sisi lain, volume pengunjung menjadi perdebatan. Bagi pengusaha: semakin banyak pengunjung, semakin besar keuntungannya. Ini menjadi salah satu isu penting saat awal perdebatan pembentukan taman nasional. Sebaliknya, para pemerhati lingkungan mengeluh tentang kerusakan yang ditumbulkan oleh para pengunjung yang banyak. 


\section{b. Taman Nasional Sebagai Identitas Nasional}

Berbagai latar belakang budaya dan politik mempengaruhi terbentuknya Yellowstone. Tujuan utama penetapan taman nasional tersebut adalah membangun identitas nasional, yang membedakan budaya dan lanskap alam dari Eropa — negeri asal para warga negara Amerika Serikat.

Gagasan pelestarian lanskap di taman nasional sebagai identitas nasional ini mempunyai dua alasan utama. Pertama, bentang alam monumental ini menunjukkan Amerika Serikat unik dan tempat berkumpulnya orangorang Eropa yang berbeda dari negara asalnya. Ini semacam ikhtiar membentuk identitas nasional yang berbeda dengan Eropa. Kedua, dengan melindungi lanskap alam dapat menumbuhkan jiwa patriotisme warga Amerika Serikat melalui kunjungan ke taman monumental ini. Pada tahun 1860-an, pemerintah pusat Amerika Serikat mencoba menyatukan kembali negara-negara bagian setelah adanya perang saudara. Lanskap alam tersebut menjadi tempat bertemu dan menjadi simbol identitas nasional Amerika (Haines, 1996).

Tidak hanya di Amerika Serikat, taman nasional juga menjadi identitas nasional bagi orang Eropa yang bermukim di Afrika. Kruger, didirikan pada 1926, mempunyai peran penting dalam menunjukkan identitas nasional orang kulit putih atau pendatang. Hal yang sama juga terjadi di Taman Nasional Matopos, Zimbabwe. Di taman tersebut terdapat sebuah makam tokoh orang kulit putih, yang dijadikan simbol kebanggaan orang kulit putih dan menjadi lokasi prosesi upacara negara.

Kasus Hindia Belanda agak lain. Belanda tidak mau taman nasional sebagai identitas bangsa. Untuk itu, ia tidak mau menggunakan istilah taman nasional. Tak heran yang muncul istilah seperti Natuurnomumenten untuk Hindia Belanda.

Selain sentimen dengan Amerika Serikat, Pemerintah Kolonial ini takut menggunakan kata "nasional". Sebab waktu itu pergerakan untuk melawan imperialisme sedang gencargencarnya. Saat itu pemuda pergerakan Indonesia, seperti Bung Karno, Bung Hatta, dan Syahrir, sedang melakukan perjuangan untuk terbebas dari penjajah. Lalu di tahun 1928, Sumpah Pemuda dikumandangan oleh para pemuda dari perwakilan daerah di Indonesia. Karena situasi seperti itu, Belanda takut menggunakan istilah taman nasional, yang bisa dianggap mengakui Indonesia.

\section{c. Taman Nasional Sebagai Kawasan Konservasi}

Pembentukan taman nasional di Amerika Serikat merupakan tonggak gerakan konservasi di dunia. Ide Amerika Serikat pada akhir abad 19 ini telah menjadikan gerakan konservasi menjalar ke berbagai negara lain. Aktivis, penulis, politikus, dan swasta seolah merayakan keberadaan taman nasional sebagai indikator kesuksesan konservasi. Dari yang semula untuk wisata, pengelolaan taman nasional bergeser menjadi cadangan sumber daya alam. Semangat untuk mengalokasikan dan menjaga sebuah lahan, yang disebut taman nasional, diakui dapat melestarikan kehidupan liar atau asli di alam. Keberadaan jenis satwa dan tumbuhan ini yang mengukuhkan posisi taman nasional sebagai kawasan perlindungan keanekaragaman hayati.

Tujuan pengelolaan taman nasional pun berubah. Tidak lagi fokus ke wisata, tapi juga ke pengelolaan satwa, penyelamatan dan penelitian biodiversitas, hingga ke pengelolaan ekosistem. Taman nasional juga mengilhami para pecinta alam, peneliti biologi, dan ahli botani untuk menjadikan suatu kawasan alam menjadi lokasi perlindungan keanekaragaman hayati. Sehingga belakangan muncul istilah cagar alam, suaka 
margasatwa, dan kategori kawasan konservasi lainnya.

Supaya keaslian dan keanekaragaman hayati taman nasional terjaga, pengelolaan kawasan dengan model benteng atau Fortress Conservation menjadi populer. Seperti dibahas pada bagian sebelumnya, model ini mengadopsi Yellowstone. Artinya, taman harus bersih dari pemukiman dan kegiatan lainnya seperti beternak dan berburu. Untuk mewujudkannya, Amerika Serikat menerjunkan tentara. Tugas utama mereka adalah mengusir penduduk yang mencoba bermukim wilayah taman atau berburu. Guna mendukung tugas tentara ini, pemerintah Amerika Serikat membangun markas dan beberapa pos di dalam taman nasional. Pasukan ini juga dipersenjatai lengkap (Haines, 1996).

Selain itu, tentara juga mengendalikan satwa predator, dengan cara menembak. Waktu itu, serigala abu dan coyote-anjing hutan Amerika-tersebar cukup banyak. Dua predator itu mengincar bison dan rusa. Akibatnya, populasi bison dan rusa berkurang banyak. Untuk itu, satu-satunya cara pengendalian populasi predator adalah dengan membunuhnya.

Kehadiran tentara di taman nasional cukup efektif untuk mengamankan kawasan dan mengendalikan keanekaragaman hayati. Masyarakat pun tidak berani masuk taman nasional. Tapi pada akhirnya Amerika Serikat menarik tentara dari taman nasional, dan menggantikannya dengan petugas sipil. Meski demikian konsep konservasi benteng masih berlaku sampai hari ini.

Sementara itu, model konservasi benteng ini hanya cocok diterapkan di Amerika Serikat, dimana masalah tumpang-tindih kepemilikan lahan hampir tidak ada. Bagi negara lainkhususnya negara berkembang dan pascakolonial-metode seperti ini memunculkan masalah lain. Di negara-negara tersebut, sudah didiami masyarakat sebelum taman dibentuk.
Untuk itu keluarlah konsep pengelolaan konservasi berbasis masyarakat. Konsep ini belum matang betul karena pada hakikatnya masyarakat-yang menganggap taman tersebut adalah rumah mereka-tidak mau pindah. Hingga kini setiap negara mempunyai model pengelolaan taman nasional yang berbeda-beda.

Singkat kata, menurut Supriatna (2018) landasan didirikan taman nasional karena semakin meningkatnya arti penting pelestarian bentang alam maupun flora dan fauna. Beberapa tujuan pembentukan taman nasional meliputi perlindungan lanskap khas dan unik, dan sebagai perlindungan kehidupan liar. Supriatna (2018) menambahkan saat ini tujuan penetapan taman nasional meliputi:

1. Melindungi spesies khusus baik yang terancam ataupun spesies kunci atau prioritas, atau bisa juga disebut sebagai spesies payung. Biasanya berupa mamalia besar seperti harimau, badak, gajah, dan orang utan.

2. Melindungi kekayaan spesies yang tinggi di suatu bentang alam seperti hutan hujan tropis, terumbu karang, kawasan dengan tingkat endemik tinggi;

3. Melindungi jasa ekosistem suatu wilayah atau regional, contohnya perlindungan area tangkapan air pada daerah aliran sungai. Beberapa ahli menyatakan bahwa taman nasional sebagai tempat simpanan karbon tinggi. Dengan demikian menjaga taman nasional sama halnya ikut mengurangi terlepasnya emisi di atmosfer.

\section{d. Taman Nasional Rumah Suku Adat}

Tak bisa dipungkiri, banyak masyarakat yang sangat tergantung dengan keberadaan taman nasional. Ada yang bertempat tinggal di dalam kawasan atau hanya sekadar menggarap lahan di sana. Sebut saja di Taman Nasional Tesso Nilo, hampir separuh kawasan sudah digarap masyarakat untuk perkebunan kepala 
sawit. Di Taman Nasional Bukit Dua Puluh dikenal ada Suku Anak Dalam yang sudah turun temurun tinggal di kawasan tersebut. Di bagian Indonesia paling timur, di Papua, masyarakat aslinya adalah penghuni Taman Nasional Lorentz (Wiratno, 2004).

Mereka semua itu adalah bagian dari warga negara Indonesia. Ini artinya mereka berhak untuk menikmati dan menggunakan lahan di kawasan taman nasional. Di sisi lain, kaum konservasionis punya pandangan berbeda. Mereka berpendapat taman nasional seharusnya bersih dari masyarakat. Kadang masyarakat malah sering diklaim sebagai perambah.

Perlu dikaji lebih mendalam, siapa sebenarnya yang lebih dahulu menempati tanah yang disebut taman nasional tersebut? Jika benar penduduk asli tersebut dari dulu telah tinggal di tanah tersebut, maka bisa jadi penetapan taman nasional-lah yang harus ditelaah lagi.

Bicara tentang hal tersebut, kita harus dapat mengartikan arti dan karakteristik taman nasional itu sendiri. Selanjutnya, sudah saatnya kita melakukan refleksi atas tujuan adanya taman nasional.

Dari segi sejarah, taman nasional hanyalah sebuah gagasan dari negara Amerika Serikat untuk melabeli sebuah gunung, pantai, laut, dan hutan. Pada tahun 1872, Amerika Serikat meresmikan Yellowstone sebagai taman nasional pertama di dunia. Tujuannya tidak lain sebagai tempat yang dapat dinikmati bagi seluruh warga negara, dan menjadi simbol dari negara tersebut. Tak mau ketinggalan, kelompok lingkungan ikut bangga dengan dalih tempat tersebut sebagai habitat keanekaragaman hayati dan upaya penanganan perubahan iklim.

Pengaruh Amerika Serikat dalam mendikte dunia memang sangat besar. Buktinya lebih dari 6.500 taman nasional diadopsi di seluruh negara. Akan tetapi, setiap negara ternyata memiliki definisi dan konsep berbedabeda. Indonesia termasuk yang meniru konsep negara kapitalis ini.

Dalam kurun waktu 40 tahun, pemerintah Indonesia telah mengakui dan menetapkan 54 taman nasional. Luasnya pun bervasiasi. Ada yang hanya 5.000 hektar hingga 2,4 juta hektar. Pertanyaannya: apakah semua taman nasional di Indonesia mencerminkan keinginan warga negara Indonesia?

Menjawab pertanyaan ini, kita perlu tahu alasannya dari salah satu Presiden Amerika Serikat, Theodore Roosevelt. Dia dikenal sebagai Presiden Amerika Serikat yang gencar terhadap konservasi alam dan pembentukan taman nasional. Dalam sebuah tulisan, Presiden Roosevelt mengatakan, "Kita seharusnya mengakui bahwa usaha pembentukan taman nasional pada dasarnya adalah gerakan demokrasi, yang memberikan manfaat bagi seluruh warga negara tanpa terkecuali."

Ini menunjukkan taman nasional harus terbuka untuk seluruh warga negara. Dalam konteks Indonesia, taman nasional semestinya memberikan kesejahteraan bagi seluruh rakyat. Bukan saja bagi mereka yang senang berwisata atau berpetualang, tapi juga harus membawa manfaat bagi masyarakat yang bergantung pada taman nasional. Bagi sebagian masyarakat yang sudah turun-temurun hidup di dalam kawasan taman nasional, kawasan hutan konservasi ini adalah rumah mereka. Konsep taman nasional semestinya menggandeng mereka untuk samasama menjaga dan memanfaatkan kekayaan kawasan tersebut. Bukan sebaliknya, masyarakat justru diusir dari taman nasional, rumah mereka sendiri.

\section{Kesimpulan dan Rekomendasi}

\section{a. Kesimpulan}

Berdasarkan tinjauan ekologi politik dari aspek sejarah, peran atau makna taman nasional 
tidak hanya sekedar untuk kepentingan konservasi alam saja. Taman nasional sebagai destinasi wisata malahan menjadi tujuan utama pembentukan taman nasional. Terlebih turisme alam di masa seperti ini akan menjadi sebuah tren, terlebih saat masa pandemi Covid-19 seperti saat ini. Menjaga jarak dengan pengunjung lain merupakan alasan kuat untuk memilih tamasya alam.

Namun, menjadikan taman nasional hanya sebagai destinasi wisata menuai banyak perdebatan. Banyak faktor yang mempengaruhinya. Salah satunya adalah pembentukan dan pengelolaan taman nasional-khususnya sebagai destinasi wisatatidak terlepas dari kontroversi. Isunya antara lain: mulai dari perbedaan paradigma arti dan tujuan konservasi, hingga maraknya spekulan konsesi wisata.

Beberapa konservasionis berpendapat bahwa kunjungan pelancong akan berakibat negatif pada ekosistem. Utamanya karena masifnya pembangunan infrastruktur, persoalan sampah, dan perubahan bentang alam. Kelompok ini mengklaim kehidupan liar lebih penting daripada manusia. Tak heran mereka berpendapat taman nasional harus bebas dari manusia atau masyarakat. Artinya, sebagai kawasan lindung, tidak sembarangan orang boleh masuk.

Penganut aliran konservasi ini juga menganggap perlindungan kawasan adalah yang utama. Acapkali para penjaga hutan menenteng senjata api dengan dalih mengamankan areanya. Padahal sebagian status kawasannya sebenarnya belum tentu jelas juga. Selain itu, adanya petugas bersenjata api ini bukannya membuat gagah, tapi malah membuat publik tidak nyaman untuk berkunjung ke taman nasional. Perlu diingat, taman nasional sebenarnya milik publik. Artinya, setiap warga negara berhak mendapatkan manfaat dari kehadiran taman nasional tersebut. Bukannya malah ditakut-takuti dengan senjata api.

Tidak hanya bagi wisatawan, paradigma pengelolaan bersih dari manusia juga berlaku bagi masyarakat adat yang telah lama tingal di dalamnya. Sering kita dengar adanya pengusiran masyarakat adat karena kehadiran taman nasional. Padahal jika ditinjau dari segi sejarah, bisa jadi masyarakat tersebut sudah ada sebelum taman nasional ditetapkan.

Diakui, tidak mudah untuk memilih antara konservasi alam dan kebutuhan manusia. Terlebih terkait tumpang tindih status tanah. Persoalan ini memang sangat kompleks dan rumit. Berbagai kebijakan telah dicoba, namun hingga sekarang persoalan itu tak kunjung selesai. Tak hanya di Indonesia, rupanya di berbagai belahan dunia belum terdapat konsensus mengenai arti dan konsep konservasi alam.

Persoalan lainnya adalah kompetisi kewenangan pengelolaan taman. Di satu sisi, otoritas taman nasional berada di bawah pemerintah pusat. Di sisi lain, kini banyak pemerintah daerah ingin memiliki dan mengelola taman nasional. Bukan hanya soal potensi pendapatan, gejala ini justru menunjukkan besarnya komitmen pemerintah daerah dalam memandang arti penting sebuah kawasan konservasi.

Merasa tidak mendapatkan manfaat kehadiran taman nasional, pemerintah daerah akhirnya enggan mengalokasikan anggaran untuk mengembangkannya. Padahal, jika daerah bisa mengelolanya maka pusat tidak lagi pusing tentang dana dan sumber daya manusia-yang selama ini menjadi kambing hitam tidak efektifnya pengelolaan taman nasional.

Terlepas dari beberapa tantangan di atas, taman nasional mempunyai peluang sebagai wujud nyata implementasi pariwisata berkelanjutan. Artinya, pengembangan pariwisata di taman nasional justru dapat 
menggabungkan kepentingan sosial, ekonomi, dan ekologi. Jika digarap dengan serius, ekowisata ini dapat menjadi wujud nyata tujuan pembangunan berkelanjutan atau Sustainable Development Goals (SDGs). Dengan kata lain, aktivitas pariwisata alam ditengarai dapat menggabungkan tujuan konservasi alam, kebutuhan masyarakat, dan juga kepentingan pariwisata secara bersamaan. Contohnya, di Taman Nasional Gunung Rinjani, penduduk Sasak berperan aktif dalam menyediakan penginapan (homestay) dan jasa porter bagi pendaki, dengan tetap menjaga keutuhan alam.

Selain itu, taman nasional merupakan pemersatu bangsa-ia bersifat lintas batas. Bentang alam taman nasional tidak mengenal batas administrasi. Misalnya Taman Nasional Kerinci Seblat yang merupakan satu kesatuan ekosistem membentang di empat provinsi. Pemerintah, swasta, masyarakat, dan lembaga swadaya masyarakat pun bekerja bersama di sebuah lansekap.

\section{b. Rekomendasi}

Seperti kita bahas di bab sebelumnya, taman nasional mempunyai peran penting bagi pembangunan Indonesia. Beberapa makna taman nasional meliputi aspek politik (sebagai identitas bangsa), ekonomi (destinasi wisata), sosial (tempat tinggal masyarakat lokal dan suku adat), dan lingkungan (sebagai kawasan konservasi). Penggabungan beberapa fungsi tersebut memungkinkan taman nasional menjadi wujud nyata pembangunan berkelanjutan. Dengan kata lain, taman nasional dapat dikatakan sebagai agen pembangunan berkelanjutan pada level paling bawah atau lapangan, yang berhubungan langsung dengan masyarakat. Salah satu instrumen untuk mewujudkan konsep pembangunan berkelanjutan tersebut adalah melalui pengelolaan taman nasional berbasiskan pariwisata berkelanjutan.
Di sisi lain, saat ini, semua negara sedang menghadapi pandemi Covid-19. Berbagai dampak telah dirasakan baik di tingkat lokal hingga internasional. Sektor pariwisata diharapkan dapat menjadi sektor unggulan dalam pemulihan ekonomi di saat pandemi. Peluang ini dapat menjadi momentum bagi bangsa Indonesia untuk menata kembali sektor pariwisata, khususnya melalui implementasi pariwisata berkelanjutan pada taman nasional.

Untuk itu, ada beberapa rekomendasi untuk menyatukan ide peran taman nasional sebagai wujud nyata pembangunan berkelanjutan khususnya melalui pariwisata berkelanjutan dengan tantangan dan peluang di masa pandemi dan era new normal.

Pertama, seiring dengan kehadiran teknologi, pemerintah, khususnya Kementerian Pariwisata dan Kementerian Lingkungan Hidup dan Kehutanan, dapat mengembangkan wisata virtual taman nasional. Bentuknya bisa berupa video 360 derajat, siaran langsung dari kamera web, hingga tamasya multimedia interaktif. Dengan begitu, masyarakat bisa menikmati keindahan taman nasional di mana pun berada. Pengunjung dapat melihat pemandangan dan mendengar suara alam bak aslinya tanpa harus datang.

Penggunaan teknologi ini diharapkan dapat menjadi alternatif bagi masyarakat yang masih enggan keluar rumah karena khawatir akan tertular virus korona. Prosedur untuk bepergian pun masih ribet: harus mengikuti tes cepat dan protokol kesehatan lainnya. Tiket dan ongkosnya pun mahal. Terlebih letak sebagian besar taman nasional jauh dari tempat tinggal.

Tur virtual ini juga dapat dijadikan sebagai peranti promosi. Harapannya, jika pandemi sudah berakhir dan kehidupan berjalan normal, kampanye ini akan meningkatkan jumlah wisatawan. Dengan demikian, roda perekonomian baik di lokal dan nasional akan bergerak. 
Kedua, pengelola taman, yaitu Balai Taman Nasional, harus mengubah paradigma: dari sekedar pengamanan ke manajemen wisatawan. Orientasinya tidak hanya mengamankan kawasan, tapi memberikan pelayanan prima. Pariwisata merupakan sektor jasa. Artinya, pengelola wajib memberikan rasa aman dan nyaman kepada pengunjung. Tentunya, tanpa mengesampingkan masyarakat dan ekologi.

Ketiga, pemerintah pusat dan daerah diharapkan dapat memperbaiki iklim investasi pariwisata, khususnya untuk mempermudah pelibatan swasta . Dalam mengembangkan sebuah destinasi wisata, perlu peran swasta melalui sistem konsesi. Banyak yang berhasil dengan model ini. Contohnya Taman Nasional Bali Barat. Tapi, banyak juga konsesi yang mangkrak atau tidak beroperasi. Meski ada sistem evaluasi, namun izin spekulan ini jarang yang dicabut. Tak hanya itu, pembangunan infrastruktur penunjang pun jadi terhambat karena permasalahan lahan ini.

Keempat, Balai Taman Nasional diharapkan dapat melibatkan secara aktif desa atau masyarakat lokal dalam pengelolaan taman nasional sebagai destinasi wisata. Pelibatan masyarakat lokal dalam kegiatan wisata juga menjadi elemen penting dalam mewujudkan wisata berkelanjutan. Peran mereka, misalnya, bisa menjadi pemandu, penyedia akomodasi, dan menjajakan makanan. Tentu saja, pengelola harus melatih, dan kalau perlu memberikan bantuan ekonomi produktif. Sehingga masyarakat tidak lagi menjadi penonton, tapi pelaku aktif wisata di taman nasional.

Akhir kata, saat ini kita memasuki sebuah tatanan baru. Sebuah momen untuk menghidupkan kembali makna taman nasional sebagai destinasi wisata bagi seluruh warga, sekaligus sebagai identitas nasional.
Boomgaard, Peter. (1999). Oriental Nature, its Friends and its Enemies: Conservation of Nature in Late-Colonial Indonesia, 18891949. Dalam Environment and History, 5: 257-292.

Kay Chen, Will Enger, Jackey Yu, and Cherie Zhang. 2020. Hitting the road again: How Chinese travelers are thinking about their first trip after COVID-19. https://www.mckinsey.com/featuredinsights/asia-pacific/hitting-the-roadagain-how-chinese-travelers-arethinking-about-their-first-trip-aftercovid-19 diakses 10 Agustus 2020.

Haines, Aubrey L. 1996. The Tellowstone Story-A History of Our First National Park, Rev. ed. Vol I. Yellowstone National Park, WY: Yellowstone Association.

Jepson, P. dan R.J Whittaker. 2002. Histories of

Protected Areas: Internationalism of Conservationist Values and Their Adoption in the Netherlands Indies (Indonesia). Dalam Environment and History, 8:129-172.

Kusumasumantri, P.Y. 2016. Sejarah 5 Taman Nasional Pertama. Jakarta: Sekretariat Ditjen KSDAE, Kementerian Lingkungan Hidup dan Kehutanan.

McManus, P. 1999. Histories of Forestry: Ideas, Networks and Silences. Environment and History 5: 185-208.

Robbins, Paul. 2019. Political Ecology: A Critical Introduction. NJ: John Willey \& Sons.

Runte, Alfred. 2010. National Parks: the American Experience. Maryland: Taylor Trade Publishing.

Supriatna, Jatna. 2008. Melestarikan Alam Indonesia. Jakarta: Yayasan Obor Indonesia.

Wiratno. 2001. Berkaca di Cermin Retak: Refleksi Konservasi dan Implikasi bagi Pengelolaan Taman Nasional. Bogor: Forest Press.

\section{Daftar Pustaka}

